\title{
Raising lambs on natural and cultivated pastures in the conditions of Lapland
}

\author{
LIISA SYRJÄLÄ \\ Department of Animal Husbandry, University of Helsinki, SF-00710 Helsinki 71
}

Abstract. The growth of lambs on natural and cultiavated pastures was studied in 1979-1980 in northern Lapland at $69^{\circ} 40^{\circ} \mathrm{N}$ and $27^{\circ} 05^{\prime} \mathrm{E}$. The natural pasture was a peninsula covered by various wild grasses, bearing willow and birth and with sedge and horsetail by the shore. On the cultivated pasture timothy predominated. The experiments started in mid June, when the age of the lambs averaged three months, and lasted to mid September. During that time, the animals received no supplemental feeds. The grazing density on the natural pasture was $1.5-3.2 \mathrm{lambs} / \mathrm{ha}$ and on the cultivated pasture $15-20 \mathrm{lambs} / \mathrm{ha}$.

The lambs on the natural pasture grew significantly slower $(\mathrm{P}<0.05)$ than those on the cultivated pasture. The difference in live-weight gain was especially marked in June and from the beginning of August. In lambs moved from the natural pasture to the cultivated pasture in mid August the growth rate was somewhat better than in lambs kept on the natural pasture throughout, but growth diminished in all the lambs in September. The slaughter criteria were also better for the lambs on the cultivated pasture than for the others.

\section{Introduction}

Grazing is the most natural way of feeding sheep, and being ruminants, sheep are well able to utilize areas not suitable for cultivation. Such marginal areas exist on a large scale in Finland, especially in the north, and the purpose of this study was to compare the growth of lambs on natural and cultivated pastures in northern Lapland. The experiments were made in 1979-1980 at Muddusjärvi experimental farm in Inari commune, at $69^{\circ} 40^{\prime} \mathrm{N}$ and $27^{\circ} 05^{\prime} \mathrm{E}$ (see also SYRJÄLÄ 1981).

\section{Materials and methods}

In 1979 there were 32 male lambs in the experiment, which lasted 10 weeks, 3.7-10.9. The lambs were in one group on natural pasture.

In 1980 there were 43 lambs in the experiment, both female and castrated male lambs. The experiment lasted 11 weeks, 17. 6.-9.9. The lambs were divided into three similar groups, which were fed as follows:

Group 1: Kept throughout the experiment on natural pasture

Group 2: Kept throughout the experiment on cultivated pasture

Group 3: Kept on natural pasture until 12.8. 1980 and after that on cultivated pasture. 
Groups 1 and 3 were kept together on the natural pasture until 12.8. -80 , when group 3 was put together with group 2 on the cultivated pasture.

In both experiments the lambs were finsheep born in March-April. During the experiments they did not have any supplemental feeds except licking stone, mainly containing $\mathrm{NaCl}$.

The cultivated pastures and the way in which they were used were as described earlier (SYRJÄLÄ 1981). The natural pasture was as a peninsula about 10 ha in area. It was covered by various wild grasses and also had abundant willow and birch; near the water grew sedge and horsetail. The composition and yield of this natural pasture was studied in 1979 by taking samples of grass and leaves every second week (SYRJÄLÄ 1981).

Results

Feeding value of the pastures

The leaves of willow were richer in protein and poorer in crude fibre than the leaves of birch and wild grasses (Fig. 1). At the beginning of July the crude protein content of the willow leaves was about $20 \%$ of dry matter, but by the end of July it had decreased to $16 \%$ and during August it fell to $13 \%$. The crude protein content of the birch leaves was about $16 \%$ during the whole of July and also decreased to $13 \%$ during August. There were only small changed in the crude fibre content of

Fig. 1. Crude protein and crude fibre

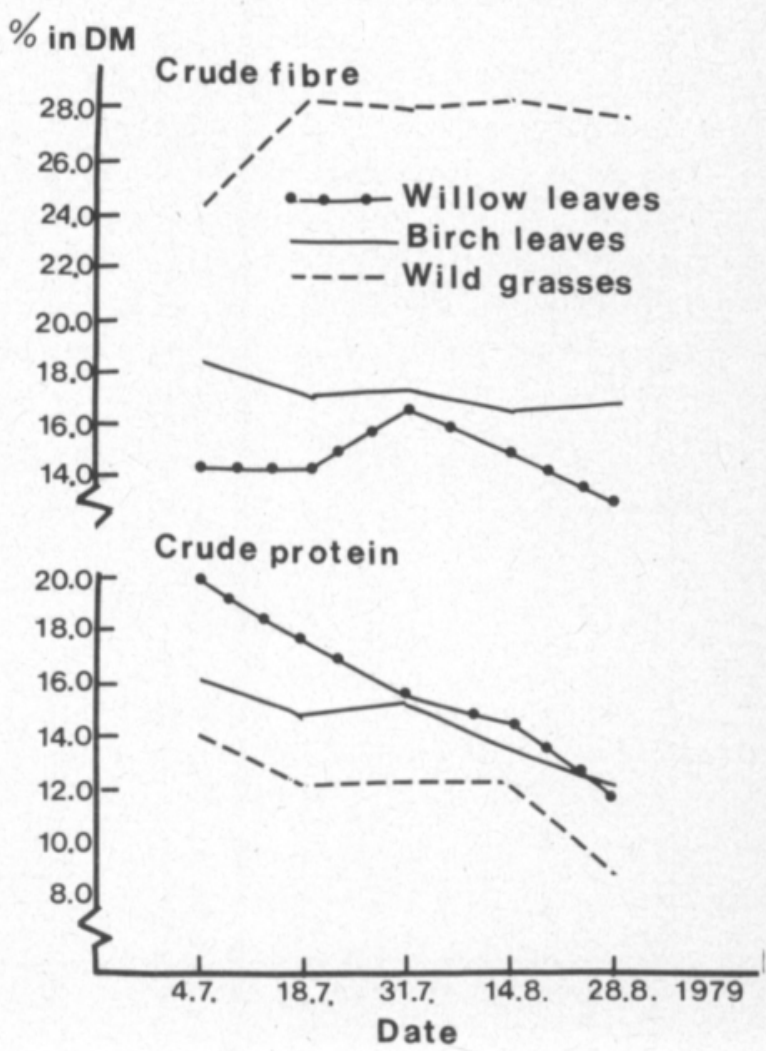


these leaves during the experimental period. In willow leaves it remained at 14-16 $\%$ and in birch leaves at $17-18 \%$ during July and August. The protein content of the grasses was rather low throughout the period: in July 13-14\% and in August $10-12 \%$ of dry matter. Their crude fibre content increased in the middle of July to $28 \%$ of dry matter, and remained at this level until the end of August.

The average dry matter content in the leaves of willow and birch was $34-35 \%$ and in wild grasses about $28 \%$.

The in vitro digestibility of organic matter in the leaves and wild grasses was rather low compared with the value for the grass in the cultivated pasture: $40-45 \%$ vs. $60-70 \%$. The nutritive value of the grass in the cultivated pasture was fairly good and did not fluctuate greatly during the experiments (SYRJÄLÄ 1981). The lambs on the natural pasture most probably ate various leaves and the bark of willow. At the end of the summer they also ate horsetail.

\section{Live-weight gain and carcass quality}

In 1979 the growth of the lambs was almost linear until the end of August, the average live-weight gain being $146 \mathrm{~g} / \mathrm{day}$, but during September (28. 8.-10.9.) their growth stopped completely and they lost weight. Thus the average live-weight gain for the whole experiment was only $81 \mathrm{~g} / \mathrm{day}$. The slaughter criteria showed that their carcasses were almost fat-free. The carcass percentage averaged 36.

In 1980 the lambs on the natural pasture grew significantly slower during the whole experiment than those on the cultivated pasture ( $\mathrm{P} \quad 0.05$, Fig. 2). The average liveweight gain of the lambs on the cultivated pasture (group 2) was 148 $\mathrm{g} /$ day (Table 1). The corresponding gain of the lambs kept first on natural pasture and later on cultivated pasture (group 3) was $127 \mathrm{~g} /$ day, and that of the animals kept throughout on natural pasture (group 1) was $101 \mathrm{~g} /$ day.

In June all the lambs grew slowly. On the natural pasture the best growth was obtained in July, $180 \mathrm{~g} /$ day in group 1 and $188 \mathrm{~g} /$ day in group 3, but by August their growth had already started to slow down; in the first part of August it was only $50-53 \mathrm{~g} / \mathrm{day}$. The lambs in group 1 , who continued to be on natural pasture, stopped growing completely after August. The lambs in group 3, which were moved to the cultivated pasture on 13.8. 1980, grew better in the second half of August,

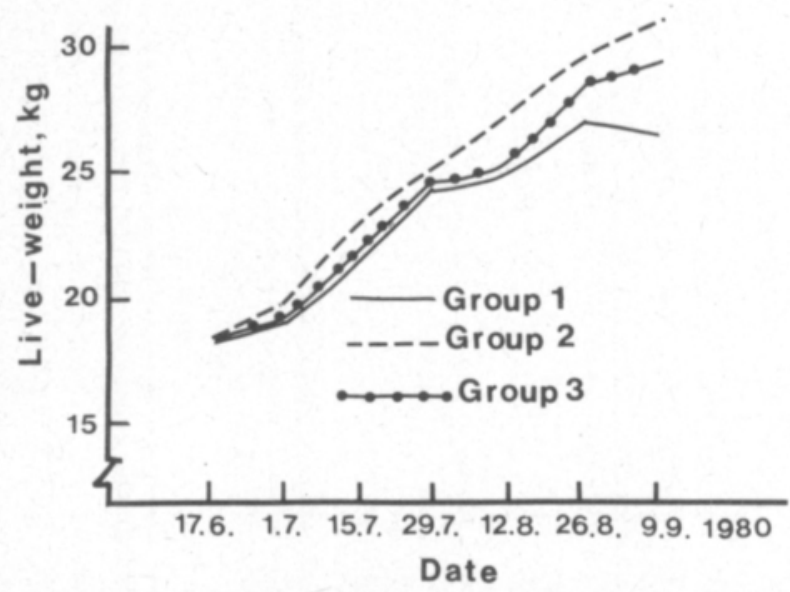

Fig. 2. Live-weight gain of lambs in 1980.

Group 1, on natural pasture

Group 2, on cultivated pasture

Group 3, on natural pasture until 12.8.

on cultivated pasture from 13.8. 
though their growth slowed down in September. The growth of the lambs in group 2 remained constant during July and August and decreased only in September.

The slaughter results were best in group 2 (Table 2). The dressing percentage was about same, however: $39 \%$ in all the groups. The carcasses had significant more lean meat in group 2 than in group $1(\mathrm{P}<0.05)$.

\section{Discussion}

The average growth rates of the lambs on the natural pasture were not very good in these experiments, but better results have been reported earlier from natural pastures. In southern Finland lambs kept on forest pastures gained about $250 \mathrm{~g} / \mathrm{day}$ in June and July, but needed supplemental feeds in August to maintain this growth rate (SYRJÄLÄ and WESTERHOLM 1981). SANDBERG (1960) reported good growth for lambs on both hill and forest pastures, 210-220 g/day. In the experiments of BJOR and GRAFFER (1963) the growth of lambs on forest pastures averaged $152 \mathrm{~g} /$ day and in those of RUDIN (1978) $270 \mathrm{~g} /$ day.

Table 1. Live-weight gain of lambs, $\mathrm{g} / \mathrm{day}$, in 1980.

\begin{tabular}{|c|c|c|c|}
\hline Period & Group 1 & Group 2 & Group 3 \\
\hline 17. $6 .-1.7 . \ldots \ldots \ldots \ldots \ldots$ & 52 & 95 & 56 \\
\hline $2 .-15.7 . \quad \ldots \ldots \ldots \ldots \ldots \ldots$ & 176 & 214 & 186 \\
\hline 16.-29.7. $\ldots \ldots \ldots \ldots \ldots$ & 195 & 171 & 191 \\
\hline 30.7.-12.8. .......... & 50 & 140 & 53 \\
\hline 13.-26. 8. $\ldots \ldots \ldots \ldots \ldots$ & 162 & 184 & 214 \\
\hline 27. 8.-9.9. $\ldots \ldots \ldots \ldots$ & -28 & 84 & 60 \\
\hline 17. 6.-9.9. $\ldots \ldots \ldots \ldots \ldots$ & 101 & 148 & 127 \\
\hline
\end{tabular}

Group 1, on natural pasture

Group 2, on cultivated pasture

Group 3, on natural pasture until 12.8., on cultivated pasture from 13.8.

Table 2. Slaughter results in 1980.

\begin{tabular}{|c|c|c|c|}
\hline & Group 1 & Group 2 & Group 3 \\
\hline Live weight, $\mathrm{kg} \quad \ldots \ldots \ldots \ldots \ldots \ldots \ldots \ldots \ldots \ldots \ldots \ldots \ldots$ & 26.6 & 31.0 & 28.7 \\
\hline Carcass weight, $\mathrm{kg} \quad \ldots \ldots \ldots \ldots \ldots \ldots \ldots \ldots \ldots \ldots \ldots \ldots \ldots \ldots \ldots \ldots$ & 10.4 & 12.2 & 11.4 \\
\hline 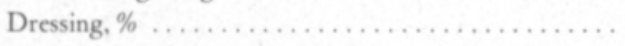 & 39.1 & 39.4 & 39.7 \\
\hline \multicolumn{4}{|l|}{ Quality points $(10-20$} \\
\hline poor - excellent) $\ldots$ & 12.9 & 13.9 & 13.6 \\
\hline \multicolumn{4}{|l|}{ Quality class, $\%$ of lambs } \\
\hline$I($ good $) \ldots \ldots$ & 50 & 82 & 67 \\
\hline II (medium) $\ldots \ldots \ldots \ldots \ldots \ldots \ldots$ & 43 & 8 & 33 \\
\hline III & 7 & 0 & 0 \\
\hline \multicolumn{4}{|l|}{ Fatness of carcass, $\%$ of lambs } \\
\hline $\mathrm{T}($ fat-free $) \ldots \ldots \ldots \ldots \ldots \ldots \ldots \ldots$ & 79 & 36 & 78 \\
\hline A (thin fat cover) $\ldots \ldots \ldots \ldots \ldots$ & 21 & 64 & 22 \\
\hline
\end{tabular}

Group 1, on natural pasture

Group 2, on cultivated pasture

Group 3, on natural pasture unti. 12.8., on cultivated pasture from 13. 8. 
In the present experiments the slow growth of the lambs at the beginning of summer was at least partly due to the fact that the supply of food from the natural pasture was insufficient. At the end of the summer the growth rate of the lambs was restricted by the decrease in the nutritive value of the wild plants. The cold nights during that time also played a role. In 1979 the first frosty nights occurred on 2428 August. The nutritive value of the grass on the cultivated pasture remained fairly good throughout the experiments.

The production of natural pastures varies with the soil and vegetation. The correct grazing density is thus very difficult to determine exactly. If the density is too high, harmful overgrazing may be expected. In very poor areas (WELCH 1968) densities greater than $0.01 \mathrm{animal} / \mathrm{ha}$ it is not possible to have. STEEN et al. (1972) determined the grazing density according to the production, as follows:

\begin{tabular}{cc}
\hline $\begin{array}{c}\text { Net production } \\
\text { of pasture } \\
\text { f.u./ha }\end{array}$ & Sheep/ha \\
\hline 300 & 1.2 \\
1000 & 3.6 \\
1670 & 5.8 \\
2330 & 8.1 \\
\hline
\end{tabular}

For sheep grazing to be an economic proposition, the yield of natural pastures should be over 750 f.u./ha, and pastures that produce over 2200 f.u./ha are recommended for lambs (MATSON 1974). In the present experiments the grazing density of the natural pastures in 1979 averaged $3.2 \mathrm{lambs} / \mathrm{ha}$; in 1980 from 17 June to 12 August it was $2.9 \mathrm{lamb} / \mathrm{ha}$ and from 13 August to 9 September 1.5 lambs/ha. The average yield from the wild grass in July was $200-240$ f.u./ha and in August 260-320 f.u./ha, but the animals also ate the leaves of other plants and their proportion in the diet cannot be evaluated. On the cultivated pasture the grazing density was 15-20 lamb/ha (SYRJÄLÄ 1981).

Acknowledgements. - I wish to express my best thanks to Mrs. Aulikki Moisio and Mr. Kyösti Mäenpää and all the students in Muddusniemi for technical help.

\section{References}

BJOR, K. \& GRAFFER, H. 1963. Beitendersokelser på skogsmark. 365 p. Gjobvik.

MATSON, C. 1974. Studier i landskapsvård 1. Fårskötsel 10: 7-9.

RUDIN, Ö. 1978. Inga vall plantor skadade. Fårskötsel 5: 8-9.

SANDBERG, M. 1960. Avdråttskontroll med sau på skogs- og fjellbeite. Forskn. fors. Landbr. 11: 311325.

STEEN, E., MATSON, C. \& SVENSSON, C. 1972. Landskapsvård med betesdjur. Akt. från Lantbr. högsk. 182. Uppsala.

SYRJÄLÄ, L. 1981. Pasture feeding of lambs with and without supplements in the conditions of Lapland. J. Scient. Agric. Soc. Finl. 53: 139-145.

— \& WESTERHOLM, B. 1981. Lampaiden kãyttő metsälaitumilla. Kehittyvä Maatalous (in press).

WELCH, D. 1968. Sheep grazing in Northern England. Proc. Symp. on Hill land productivity. Eur. Grassl. Fed. 32: 173-176.

Ms received May 22, 1981. 


\title{
Luonnonlaidun ja viljelty laidun karitsoiden kasvatuksessa Lapin olosuhteissa
}

\author{
Liisa Syrjälä \\ Helsingin yliopiston kotieläintieteen laitos, 00710 Helsinki 71
}

Helsingin yliopiston omistamalla Muddusniemen Tutkimusasemalla Inarissa verrattiin vuosina 19791980 luonnonlaitumia ja viljeltyjä laitumia karitsoiden kasvatuksessa ilman lisärehuja. Luonnonlaitumena oli noin 10 hehtaarin suuruinen joen ja järven ympäröimä niemeke, jossa kasvoi erilaisia heinä- ja ruohokasveja sekä pajua ja koivua. Veden rajassa oli myös saraa ja järvikortetta. Viljelty laidun oli timoteivaltaista nurmea. Laiduntamistiheys luonnonlaitumella oli $1.5-3.2 \mathrm{karitsaa} / \mathrm{ha}$ ja viljelyllä laitumella $15-20 \mathrm{karitsaa} / \mathrm{ha}$.

Vuoden 1979 tutkimus rajoittui 32 pässikaritsan kasvun seurantaan luonnonlaitumella. Vuonna 1980 oli kokeissa uuhikaritsoita ja kuohittuja pässikaritsoita yhteensä $43 \mathrm{kpl}$. Karitsat jaettiin kolmeen ryhmään, joiden kasvatusmuoto oli seuraava:

Ryhmä 1: koko koekauden luonnonlaitumella

Ryhmä 2: koko kockauden viljellyllä laitumella

Ryhmä 3: luonnonlaitumella 12.8. asti ja loppuaika viljellyllä laitumella.

Kokeet aloitettiin kesäkuun puolenvälin jälkeen ja lopetettiin syyskuun puolivälissä. Karitsoiden ikä kokeiden alkaessa oli keskimäärin kolme kuukautta.

Keskimääräinen päivittäinen kasvu koko kokeen aikana oli v. $197981 \mathrm{~g} / \mathrm{eläin} \mathrm{ja} \mathrm{v.} 1980$ ryhmässä 1101 $\mathrm{g}$, ryhmässä $2148 \mathrm{~g}$ ja ryhmässä $3127 \mathrm{~g}$. Erot ryhmien 1 ja 2 välillä olivat merkitsevät $(\mathrm{P}<0.05)$. Kun ryhmä 3 siirrettiin 12.8. viljellylle laitumelle, sen kasvutulokset paranivat ryhmään 1 verrattuna. Teurastulokset olivat parhaimmat ryhmällä 2. Teurasprosentti oli kuitenkin lähes sama kaikissa ryhmissã eli keskimäärin 39.

Tutkimustulokset osoittivat, että luonnonlaituimien edullisin hyväksikäyttö Lapin olosuhteissa rajoittuu vain keskikesään eli heinäkuuhun. Kesäkuussa luonnonlaitumella on vielä suhteellisen vähän rehua tarjolla ja karitsoiden kasvu näinollen heikkoa. Elokuussa luonnonlaitumen rehu taas on jo täyttävämpää ja ravintoköyhempää kuin heinäkuussa, mikä myös hidasti kasvua. Syyskuussa luonnonlaitumilla olevat karitsat jopa menettivåt painoaan. 